\section{En kvinne i 50-årene med venstre grenblokk og tilbakevendende arytmier}

NOE Å LARE AV

\section{FREDRIK EIKA}

E-post: eikafredrik@gmail.com

Medisinsk avdeling

Diakonhjemmet Sykehus

Fredrik Eika er lege i spesialisering i indremedisin og tidligere LIS1-lege ved Ålesund sjukehus.

Forfatteren har fylt ut ICMJE-skjemaet og oppgir ingen interessekonflikter.

\section{JOHNNY VEGSUNDVÅG}

Kardiologisk seksjon

Medisinsk avdeling

Ålesund sjukehus

Johnny Vegsundvåg er ph.d., spesialist i hjertesykdommer og i indremedisin, overlege og er medlem i

Norsk cardiologisk selskaps arbeidsgruppe i ekkokardiografi.

Forfatteren har fylt ut ICMJE-skjemaet og oppgir ingen interessekonflikter.

\section{HILDE HELLEBUST HAALAND}

Kardiologisk seksjon

Medisinsk avdeling

Ålesund sjukehus

Hilde Hellebust Haaland er spesialist i hjertesykdommer og i indremedisin og overlege.

Forfatteren har fylt ut ICMJE-skjemaet og oppgir ingen interessekonflikter.

\section{HÅKON JOHANSEN}

Avdeling for nukleærmedisin og medisinsk fysikk

St. Olavs hospital

Håkon Johansen er spesialist i nukleærmedisin og overlege.

Forfatteren har fylt ut ICMJE-skjemaet og oppgir ingen interessekonflikter.

\section{HALLVARD FREMSTAD}

Revmatologisk avdeling

Ålesund sjukehus

Hallvard Fremstad er spesialist i revmatologi og overlege.

Forfatteren har fylt ut ICMJE-skjemaet og oppgir ingen interessekonflikter.

En kvinne i 50-årene utviklet symptomer i form av tørrhoste og ukarakteristiske brystsmerter. Den påfølgende tiden var preget av tilbakevendende arytmier og etter hvert svekket hjertefunksjon. Tverrfaglig utredning identifiserte en sjelden tilstand. 
En kvinne i 5o-årene oppsøkte fastlegen grunnet tørrhoste, diskré trykk for brystet både i hvile og aktivitet samt opplevelse av mangelfull pulsstigning ved aktivitet. Ved undersøkelse var det obstruktive fremmedlyder over lungene. EKG viste normal sinusrytme med tilkommet venstre grenblokk. Pasienten var overvektig, med BMI på $32 \mathrm{~kg} / \mathrm{m}^{2}$, og hadde aldri røkt. Fra tidligere hadde hun migrene og lett forhøyet blodtrykk. Kandesartan 8 mg daglig var eneste faste legemiddel. Bortsett fra diabetes mellitus type 1, arteriell hypertensjon og hypotyreose forelå det ingen sykdommer i familien. Fastlegen startet opp med inhalasjonsbehandling med steroider og betaagonister på mistanke om obstruktiv lungesykdom, men etter to uker hadde ikke dette hatt effekt på symptomene. Røntgen toraks var uten patologiske funn. Hun ble henvist til videre vurdering ved sykehuset.

Differensialdiagnosene ved tørrhoste og brystsmerter er mangfoldige og inkluderer patologi i luftveier, lunger, hjerte, øvre gastrointestinalkanal og brystkasse. Venstre grenblokk vil ofte være assosiert med underliggende hjertesykdom, men kan også skyldes isolert progressiv degenerasjon i hjertets ledningssystem.

Ved påfølgende poliklinisk sykehusutredning tre uker senere forelå det normal organstatus ved generell klinisk undersøkelse og ingen fremmedlyder over lungene. Hun var afebril, hadde forhøyet blodtrykk på 16o/77 mm Hg, og EKG viste regelmessig sinusbradykardi på 52 slag/min, normal PQ-tid, venstre grenblokk med QRS-varighet $128 \mathrm{~ms}$ og repolariseringsendringer. Oksygenmetning, gassdiffusjonsmåling og spirometrifunn lå innenfor det normale. Røntgen toraks var fortsatt uten patologiske funn. Bred blodprøveutredning viste subklinisk hypotyreose med tyreoideastimulerende hormon (TSH) 3,8 mU/L (referanseområde o,5-3,6) og fritt T4 15 pmol/L (11-17). Ellers var det normale funn, inklusiv troponin T, B-type natriuretisk peptid (BNP), senkningsreaksjon $(5 \mathrm{~mm} / \mathrm{t})$, angiotensinkonverterende enzym (ACE) og antinukleære antistoffer.

Ekkokardiografi viste en normalt dimensjonert venstre ventrikkel med endediastolisk diameter $4,4 \mathrm{~cm}(\leq 5,5)$, normal systolisk sammentrekking med ejeksjonsfraksjon $>50 \%$ og normalt fyllingstrykk. Ventrikkelen hadde normale veggtykkelser på $9 \mathrm{~mm}$ uten lokale veggfortynninger. Det forelå ingen dyssynkroni mellom venstre ventrikkels veggavsnitt, noe som ofte forekommer sekundært til venstre grenblokk. Høyre ventrikkel var normalt fungerende med grensehøyt systolisk pulmonalarterietrykk estimert til $39 \mathrm{~mm} \mathrm{Hg}$. Ved arbeids-EKG utviklet hun verken brystsmerter eller arytmier, men hadde venstre grenblokk under hele belastningen. En litt lav pulsstigning til $117 \mathrm{slag} / \mathrm{min}$ ble relatert til prematurt avsluttet belastning.

På grunn av brystsmertene og venstre grenblokk ble hun neste dag poliklinisk videre utredet med stressekkokardiografi i form av trinnvis økende dobutamininfusjon. Grunnet ikke-tilfredsstillende sinusfrekvensstigning til bare $100 \mathrm{slag} / \mathrm{min}$, ble det til sist på høyeste dobutaminnivå gitt tillegg av atropin intravenøst. Det oppstod deretter atrieflutter med rask ventrikkelfrekvens på ca. $200 \mathrm{slag} / \mathrm{min}$, men uten at pasienten ble besværet. Man stanset dobutamininfusjonen og ga metoprolol intravenøst, med påfølgende ventrikkelfrekvensreduksjon til ca. 120 slag/min. Under belastningen tilkom det normal kontraksjonsøkning i alle myokardavsnitt. Pasienten ble elektrokonvertert i to omganger før hun slo om fra atrieflutter til stabil sinusrytme.

Stressekkoundersøkelsen ga ikke holdepunkt for obstruerende koronarsykdom. Videre hadde ekkokardiografi vist normale forhold. Det ble derfor konkludert med at hennes venstre grenblokk sannsynligvis var degenerativt betinget, noe som ikke er uvanlig. Utløsning av supraventrikulære takyarytmier kan en sjelden gang forekomme ved dobutaminstressekkokardiografi, og atrieflutterepisoden under stressekkoundersøkelsen ble derfor tilskrevet dette. Utredningen var for øvrig normal. Hun forlot sykehuset med en $\emptyset$ kning av kandesartan til $16 \mathrm{mg}$ daglig for å bedre blodtrykket.

To uker seinere fikk pasienten residiv av rask atrieflutter og ble innlagt på medisinsk avdeling. Her ble hun elektrokonvertert og satt på peroral antikoagulasjonsbehandling med rivaroksaban $20 \mathrm{mg}$ daglig samt sotalol $80 \mathrm{mg}$ to ganger daglig. Røntgen toraks viste fortsatt normale funn, men tørrhosten vedvarte. Betablokker ble etter hvert seponert 
grunnet sinusbradykardi rundt 3o-tallet per minutt, med ledsagende svimmelhet. De påfølgende ukene ble pasienten innlagt med rask atrieflutter og fikk elektrokonvertering seks ganger. 24 timers EKG-registrering viste syk sinusknute med intermitterende sinoatrialt (SA) blokk med enkelte pauser, hvorav den lengste var på 2,8 sekunder. Hun anga ingen kardiale plager under rytmeregistreringen, og det ble ikke funnet indikasjon for permanent pacemaker. Pasienten ble overflyttet til regionsykehus og behandlet med isthmusablasjon. Under prosedyren fikk hun forbigående sinusarrest og persisterende totalt AV-blokk, og det ble lagt temporær pacemaker. Denne ble senere erstattet av en permanent tokammer-pacemaker. Ekkokardiografi etter ablasjonsprosedyren viste ikke nyoppståtte forandringer.

Ved poliklinisk oppfølging tre måneder etter ablasjonen beskrev pasienten dårlig fysisk kapasitet og en følelse av å ikke få adekvat pulsstigning ved aktivitet, i tillegg til at hun tidvis våknet opp om natten med litt tung pust. Hun angav også plager med ekstraslag og kortvarige hjertebankepisoder. Avlesning av pacemakerminnet viste hyppige supraventrikulære ekstrasystoler og dårlig kammerfrekvensstigning ved aktivitet. Hun fikk bedring av hjertebankplagene etter innsetting av metoprolol depottabletter 50 mg daglig. Imidlertid var det forhøyning i NT-proBNP til 2078 ng/L (o-247), alaninaminotransferase (ALAT) til $74 \mathrm{U} / \mathrm{L}$ (10-45), aspartataminotransferase (ASAT) til $52 \mathrm{U} / \mathrm{L}$ (15-35) og laktatdehydrogenase (LD) til 263 U/L (105-205). Det ble gjort ny ekkokardiografi som viste forhøyet fyllingstrykk i venstre ventrikkel, tilkommet redusert sammentrekking i ventrikkelseptum og fortsatt godt fungerende høyre ventrikkel. Det ble startet med bumetanid $1 \mathrm{mg}$ daglig, og kandesartan ble trappet opp til $32 \mathrm{mg}$ daglig.

Problemene med dårlig pulsstigning ved aktivitet ble knyttet til utilstrekkelig innstilling av pacemakerens kronotrope aktivitetsrespons, og denne ble gjort mer følsom. Den reduserte sammentrekkingen i ventrikkelseptum ble tillagt høyre ventrikkel-pacing.

Ved kontroll et halvt år senere beskrev pasienten økende plager med tung pust, nå etter 50-10o meter i motbakke, svarende til New York Heart Association (NYHA)hjertesviktklasse II, samt nattlig dyspné. Blodtrykket var normalt. EKG viste QRS-varighet $176 \mathrm{~ms}$, forlenget grunnet høyre ventrikkel-pacing. Ekkokardiografi viste nå tydelig venstre ventrikkel-dyssynkroni, igjen tolket til å være relatert til høyre ventrikkel-pacing. Venstre ventrikkel var dilatert, med endediastolisk diameter $6,1 \mathrm{~cm}$ og fortsatt forhøyet fyllingstrykk. Det var tilkommet atrietakykardi, som ble elektrokonvertert. Hjertesviktmedikasjonen ble intensivert: metoprolol depot ble økt til 1oo mg daglig og bumetanid til $1 \mathrm{mg}$ to ganger daglig. Ny blodprøveutredning av tyreoideastatus, senkningsreaksjon, angiotensinkonverterende enzym og antinukleære antistoffer viste normale verdier.

De påfølgende månedene fungerte pasienten i NYHA-klasse III og hadde økende nattlige sviktplager. Invasiv koronar angiografi viste åpne koronararterier. Det ble antatt at pasientens venstre grenblokk og høyre ventrikkel-pacing medførte dyssynkroni og påfølgende venstre ventrikkel-problemer, med ejeksjonsfraksjon $(E F)<35 \%$. Pasienten fikk biventrikulær pacemaker som ledd i kardial resynkroniseringsterapi (CRT). Dyspnéplagene og hosten ble deretter bedret, slik at hun kom tilbake i NYHA-klasse II.

To uker etter endring av pacemaker ble pasienten innlagt med atrietakykardi med til dels egenoverledning til ventrikler. Røntgen toraks viste markerte lungekar som ved stuvning. Ekkokardiografi viste dilatert venstre ventrikkel med endediastolisk diameter 6,o cm og svekket systolisk funksjon. Det forelå moderat mitralklafflekkasje, biventrikulært forhøyet fyllingstrykk og tilkommet pulmonal hypertensjon med estimert systolisk pulmonalarterietrykk på 50-55 mm Hg. Økningen av pulmonalarterietrykket ble vurdert til å komme fra venstre side. Atriearytmi med relativt høy ventrikkelfrekvens over tid kunne være forklaringen på progrediering av hjertesvikten.

Atrietakykardien ble vellykket elektrokonvertert. Imidlertid ble det ved rytmeovervåkning observert asymptomatiske korte løp med ventrikkeltakykardi under oppholdet. For å holde pasienten i sinusrytme ble det startet med amiodaron $200 \mathrm{mg}$ daglig, og hjertesviktmedikasjonen ble intensivert, med økning av metoprolol depot til $150 \mathrm{mg}$ daglig 
og tillegg av spironolakton $25 \mathrm{mg}$ daglig.

Ved ny ekkokardiografi under oppholdet ble venstre ventrikkels vegger nærmere vurdert. Det forelå tydelig veggfortynning til bare $5 \mathrm{~mm}$ i proksimale septum (figur 1) med ledsagende nærmest opphevet sammentrekking. Tilsvarende veggfortynninger forelå for $\emptyset v r i g$ i midtre deler av inferoseptale vegg og apikalt i nedre vegg. Det var nå gått nesten tre år siden første sykehuskontakt.

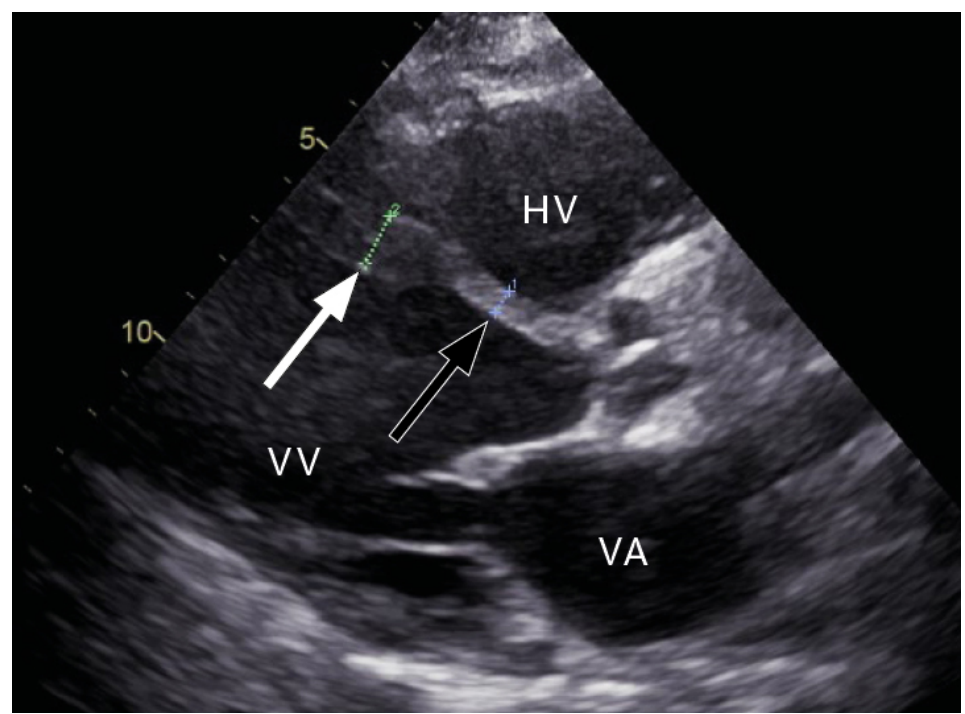

Figur 1 Parasternalt langaksebilde. Ventrikkelseptum fortynnet proksimalt (sort pil, $5 \mathrm{~mm}$ ) og normalt distalt (hvit pil, $11 \mathrm{~mm}$ ).

Vi hadde etter hvert fått økende mistanke om at hennes hjertetilstand hadde en uavklart årsak. Funnet av tydelig vegguttynning i proksimale ventrikkelseptum indikerte hjertesarkoidose.

Positronemisjonstomografi med ${ }^{18} \mathrm{~F}$-fluorodeoksyglukose kombinert med computertomografi $\left({ }^{18} \mathrm{~F}-\mathrm{FDG}\right.$ PET/CT $)$ viste utbredte funn i myokard forenlig med sarkoidose og dessuten utbredte lesjoner i lunger, lymfeknuter, lever, milt og skjelett (figur 2). Biopsier fra endokard/myokard viste fibrose og granulomatøs betennelse, og det histologiske bildet var godt forenlig med sarkoidose.

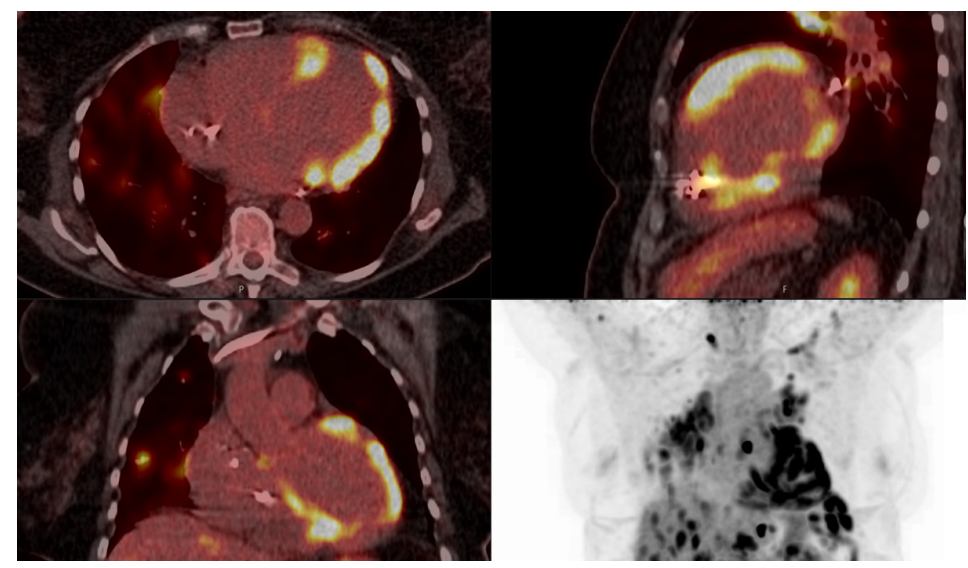

Figur 2 PET-MIP (positronemisjonstomografi med maksimal intensitet-projeksjon) og fusjonert PET/CT viser utbredt, flekkvis patologisk opptak av fluorodeoksyglukose (FDG) i myokard, høyt FDGopptak i lymfeknuter i lungehili og leverhilus, utbredte lesjoner med høyt FDG-opptak i lever, milt og skjelett.

For nærmere avklaring av de ekstrakardiale manifestasjonene ble det tatt CT toraks/abdomen/bekken. Undersøkelsen viste omfattende forandringer med holdepunkt for sarkoidoseaffeksjon i lunger, milt, lever og skjelett samt patologiske lymfeknuter i mediastinum, hilært og intraabdominalt. I utgangspunktet var det lite mistanke om malignitet, og biopsi fra lytisk forandring i pedikkel i virvelcorpus Th12 viste typiske forandringer som ved sarkoidose. På grunn av uttalt hjertesarkoidose og arytmirisiko fikk 
pasienten som forebyggende tiltak bygget ut sitt pacemakersystem med tillegg av implantert hjertestarter (implantable cardioverter-defibrillator, ICD).

Det ble startet immunhemmende behandling med prednisolon 6o mg daglig, med en nedtrappingsplan til lavere doser, og amiodaron ble prøveseponert. Hun ble innlagt etter en måned grunnet hyppige episoder med hjertebank, som viste seg å være ventrikkeltakykardiepisoder med frekvens lavere enn ICD-terapisoner. Man startet igjen med amiodaron $200 \mathrm{mg}$ daglig, og det ble etter hvert færre ventrikkeltakykardiepisoder. Den immunhemmende behandlingen ble forsterket med metotreksat 15 mg ukentlig og infliksimab $300 \mathrm{mg}$ gitt intravenøst hver 6 . uke. Hun tålte behandlingen godt og følte seg generelt litt bedre, men var fortsatt i NYHA-klasse II på tross av optimalisert medikamentell hjertesviktbehandling, med økning av metoprolol depot til $200 \mathrm{mg}$ daglig og skifte fra kandesartan til kombinasjonsmedikamentet sakubitril/valsartan $41 \mathrm{mg} / 59 \mathrm{mg}$ to ganger daglig. Ekkokardiografi viste antydet reduksjon av venstre ventrikkels dimensjoner og ellers ganske stasjonære funn. Gjentatt ${ }^{18} \mathrm{~F}$-FDG PET/CT etter tre måneder kunne ikke påvise FDG-opptak forenlig med effekt av immunhemmende behandling (figur 3 ).

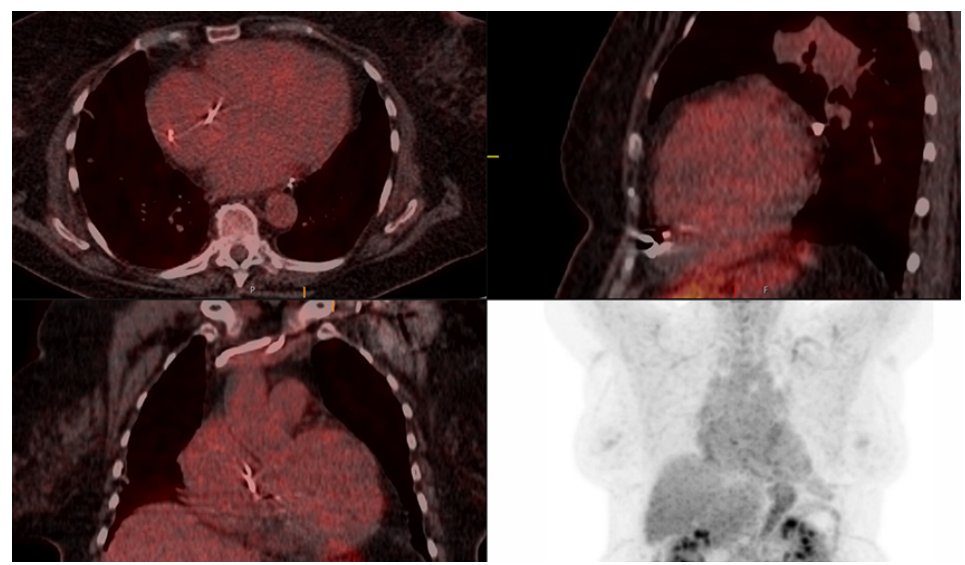

Figur 3 PET-MIP (positronemisjonstomografi med maksimal intensitet-projeksjon) og fusjonert PET/CT viser etter måneder med behandling kun fysiologisk FDG-opptak og full tilbakegang av patologisk FDG-opptak.

Steroidbehandlingen ble avsluttet etter ni måneders behandlingstid, mens infliksimab ble seponert etter ett års behandling. Deretter har hun kun brukt metotreksat som immunhemmende behandling. Hun har siden vært i ganske stabil NYHA-klasse II og har fortsatt enkelte, stort sett spontant forbigående ventrikkeltakykardiepisoder. Ekkokardiografi har vist stasjonære dimensjoner på venstre ventrikkel, med litt reduksjon av det forhøyede fyllingstrykket. Arrforandringene og endringene i ventrikkelens sammentrekking har vært stasjonære. Høyre ventrikkel har fått god funksjon, og pulmonalarterietrykket er tilbake i øvre normalområde. Underveis har hun utviklet en sannsynlig amiodaronassosiert klinisk hypotyreose med behov for tyroksinsubstitusjonsterapi. Kontrollundersøkelse med PET/CT 15 måneder etter den forrige viste fortsatt ingen tegn til residiv av hjertesarkoidose.

\section{Diskusjon}

Sarkoidose er en granulomatøs multisystemsykdom der affeksjon av lungene er den vanligste organmanifestasjonen $(1,2)$. Ekstrapulmonale forandringer kan sees i en rekke ulike organer, herunder lymfeknuter, hjerte, nervesystem, øyne, hud, lever, milt, spyttkjertler og skjelett. I en svensk studie fra 2016 fant man insidens og prevalens av symptomgivende sarkoidose til henholdsvis 12 og 160 tilfeller per 100 ooo (3). Symptomgivende sarkoidose i hjertet forekommer hos 2-7\% av personer med lidelsen, men i obduksjonsstudier er det funnet sarkoidoseforandringer i hjertet hos $25-58 \%$ av personer med tilstanden (1).

Imidlertid er hjertesymptomene hos pasienter med klinisk manifest hjertesarkoidose som regel mer dominerende enn ekstrakardiale symptomer, siden disse pasientene typisk har 
betydelig mindre ekstrakardial sarkoidose, og at hjertesarkoidosen er isolert hos opptil $2 / 3$ av disse (4). Prognosen til pasienter med hjertesarkoidose er generelt dårligere enn til pasienter der lidelsen ikke involverer hjertet (4). Prognosen ved hjertesarkoidose er alvorlig, spesielt hvis den forblir ubehandlet eller behandlingen igangsettes så sent at mye av hjertemuskelen er ødelagt (4). Det gjør det ekstra viktig å være tidlig ute med å mistenke og å utrede tilstanden.

Hjertesarkoidose kan presentere seg som asymptomatisk reduksjon av ventrikulær sammentrekking, ledningsforstyrrelser, supraventrikulære og ventrikulære takyarytmier, manifest hjertesvikt, perikardvæske og plutselig død $(1,5)$. Høygradig AV-blokk angis som den vanligste manifestasjonen av hjertesarkoidose, og tilstanden bør være en differensialdiagnose i utredning av høygradig AV-blokk (grad II (Mobitz type 2) og grad III), spesielt hos pasienter under 60 år $(4,6)$.

Dannelse av fokale granulomer er den underliggende patofysiologiske årsaken, med videre utvikling av lokalisert ødem, granulomatøs inflammasjon og til sist fibrose med postinflammatorisk arrvev. Alle deler av hjertet kan affiseres, men vanligst er lesjoner relatert til venstre ventrikkel og ventrikkelseptum $(7,8)$. Lesjonene er gjerne uspesifikke, i forskjellig grad og kan være vanskelig å skille fra blant annet koronarsykdom og andre kardiomyopatier. I tidlig fase med ødem, granulomer og inflammasjon kan affiserte myokardsegment være fortykket og gi tolkningsproblemer mot hypertrofiske hjertelidelser. Ved påfølgende progresjon av tilstanden tilkommer lokalt myokardtap og fibrose med veggfortynning og nedsatt/opphevet kontraksjon av segmentet (figur 1). Lokal fortynning av proksimale ventrikkelseptum er den vanligste postinflammatoriske lesjonen $(4,8)$. Dette funnet kan foreligge hos opp mot $50 \%$ av pasientene (8), og funnet angis som spesifikt for hjertesarkoidose $(8,9)$.

Sarkoidose bør være en differensialdiagnose ved tretthet, hoste, lavintensive brystsmerter, vekttap og dyspné. Forstørrede lymfeknuter ved røntgen toraks er et av de vanligste funnene. Sarkoidosegranulomene vil ofte produsere angiotensinkonverterende enzym, men nytten av denne biomarkøren er begrenset, og et normalt ACE-serumnivå utelukker ikke sarkoidose $(4,10)$. Hos vår pasient var serumnivået normalt ved alle målinger.

Ved utredning av hjertesarkoidose bør pasientene få utført EKG, rytmeregistrering og ekkokardiografi. Spesielt i tidlig fase av sykdommen kan ekkokardiografifunnene være normale. Magnetresonansunders $ø$ kelse (MR) med gadoliniumkontrast har vært regnet som et tidlig valg i diagnostikken av hjertesarkoidose (1). Vår pasient ble ikke unders $\varnothing \mathrm{kt}$ med hjerte-MR, siden vi lenge ikke mistenkte hjertesarkoidose. Da mistanken om sarkoidose ble reist, hadde hun allerede pacemaker, og denne kunne potensielt lage forstyrrende artefakter for tolkningen av MR-undersøkelsen. Vi fikk dessuten klare funn ved PET og også ved biopsi. PET-undersøkelse er nyttig i diagnostisk sammenheng og viser økt glukoseopptak i aktiverte immunceller i affisert vev ved pågående inflammasjon (1). Positive endokard/myokard-biopsier vil bekrefte diagnosen, men undersøkelsen kan ha lav sensitivitet grunnet sykdommens fokale lokalisasjon $(4,11)$.

En alternativ måte å diagnostisere hjertesarkoidose på (når annen årsak ikke mistenkes) er positivt biopsisvar fra ekstrakardial sarkoidose kombinert med minst ett av følgende funn: positiv effekt av steroider \pm immunhemmende behandling på kardiomyopati eller ledningsblokk, svekket venstre ventrikkels ejeksjonsfraksjon (< $40 \%$ ) uten kjent årsak, vedvarende ventrikkeltakykardi uten kjent årsak, høygradig AV-blokk, typisk flekkvis opptak ved PET-undersøkelse av hjertet, typiske funn ved MR med gadoliniumkontrast og et galliumopptak typisk for sarkoidose (12).

Omtalte pasient hadde tidlig både tørrhoste, brystsmerter og grenblokk. Retrospektivt taler dette for at hun hadde både pulmonal og kardial sarkoidose ved innledende undersøkelser. Sykehistorien illustrerer godt hvorfor sykdommen kan være vanskelig å diagnostisere, ettersom gjentatte røntgen toraks, ACE-nivå og ekkokardiografiundersøkelser ikke ga veiledende funn. 


\section{Konklusjon}

Hjertesarkoidose kan ha lite symptomer i starten, men utvikling av venstre grenblokk, totalt AV-blokk og supraventrikulære og ventrikulære arytmier gir mistanke om tilstanden, likeledes utvikling av svekket hjertefunksjon. Bildedannende undersøkelser med MR og ekkokardiografi kan være til stor hjelp i den videre kartleggingen, og spesielt vil funn av fortynnet, fibrosepreget proksimalt ventrikkelseptum kunne peke mot diagnosen. PET/CT og biopsier vil deretter kunne bidra til å bekrefte tilstanden.

\section{LITTERATUR:}

1. Vikse J, Ørn S, Jeroen de Romijn B et al. Kardial sarkoidose. Tidsskr Nor Legeforen 2018; 138. doi: 10.4045/tidsskr.17.0701. [PubMed][CrossRef]

2. Iannuzzi MC, Rybicki BA, Teirstein AS. Sarcoidosis. N Engl J Med 2007; 357: 2153-65. [PubMed][CrossRef]

3. Arkema EV, Grunewald J, Kullberg S et al. Sarcoidosis incidence and prevalence: a nationwide register-based assessment in Sweden. Eur Respir J 2016; 48: 1690-9. [PubMed][CrossRef]

4. Birnie DH, Kandolin R, Nery PB et al. Cardiac manifestations of sarcoidosis: diagnosis and management. Eur Heart J 2017; 38: 2663-70. [PubMed]

5. Kim JS, Judson MA, Donnino R et al. Cardiac sarcoidosis. Am Heart J 2009; 157: 9-21. [PubMed][CrossRef]

6. Ekström K, Lehtonen J, Nordenswan HK et al. Sudden death in cardiac sarcoidosis: an analysis of nationwide clinical and cause-of-death registries. Eur Heart J 2019; 40: 3121-8. [PubMed][CrossRef]

7. Trivieri MG, Spagnolo P, Birnie D et al. Challenges in cardiac and pulmonary sarcoidosis. J Am Coll Cardiol 2020; 76: 1878-901. [PubMed][CrossRef]

8. Chiu CZ, Nakatani S, Yamagishi M et al. Echocardiographic manifestations in patients with cardiac sarcoidosis. J Med Ultrasound 2002; 10: 135-40. [CrossRef]

9. Yamano T, Nakatani S. Cardiac sarcoidosis: what can we know from echocardiography? J

Echocardiogr 2007; 5: 1-10. [CrossRef]

10. Studdy PR, Bird R. Serum angiotensin converting enzyme in sarcoidosis-its value in present clinical practice. Ann Clin Biochem 1989; 26: 13-8. [PubMed][CrossRef]

11. Hulten E, Aslam S, Osborne M et al. Cardiac sarcoidosis-state of the art review. Cardiovasc Diagn Ther 2016; 6: 50-63. [PubMed]

12. Birnie DH, Sauer WH, Bogun F et al. HRS expert consensus statement on the diagnosis and management of arrhythmias associated with cardiac sarcoidosis. Heart Rhythm 2014; 11: 1305-23. [PubMed][CrossRef]

Publisert: 22. mars 2021. Tidsskr Nor Legeforen. DOI: 10.4045/tidsskr.20.0873 Mottatt 30.10.2020, første revisjon innsendt 18.1.2021, godkjent 8.2.2021.

(C) Tidsskrift for Den norske legeforening 2020. Lastet ned fra tidsskriftet.no 